\title{
Effective heart disease prediction system using data mining techniques
}

This article was published in the following Dove Press journal:

International Journal of Nanomedicine

\author{
Poornima Singh' \\ Sanjay Singh ${ }^{2}$ \\ Gayatri S Pandi-Jain' \\ 'L. J. Institute of Engineering and \\ Technology, Gujarat Technological \\ University, ${ }^{2}$ Institute of Life Sciences, \\ School of Science and Technology, \\ Ahmedabad University, Ahmedabad, \\ Gujarat, India
}

\begin{abstract}
The health care industries collect huge amounts of data that contain some hidden information, which is useful for making effective decisions. For providing appropriate results and making effective decisions on data, some advanced data mining techniques are used. In this study, an effective heart disease prediction system (EHDPS) is developed using neural network for predicting the risk level of heart disease. The system uses 15 medical parameters such as age, sex, blood pressure, cholesterol, and obesity for prediction. The EHDPS predicts the likelihood of patients getting heart disease. It enables significant knowledge, eg, relationships between medical factors related to heart disease and patterns, to be established. We have employed the multilayer perceptron neural network with backpropagation as the training algorithm. The obtained results have illustrated that the designed diagnostic system can effectively predict the risk level of heart diseases.
\end{abstract}

Keywords: data mining, neural network, multilayer perceptron neural network, backpropagation, disease diagnosis

\section{Introduction}

Among various life-threatening diseases, heart disease has garnered a great deal of attention in medical research. The diagnosis of heart disease is a challenging task, which can offer automated prediction about the heart condition of patient so that further treatment can be made effective. The diagnosis of heart disease is usually based on signs, symptoms and physical examination of the patient. There are several factors that increase the risk of heart disease, such as smoking habit, body cholesterol level, family history of heart disease, obesity, high blood pressure, and lack of physical exercise.

A major challenge faced by health care organizations, such as hospitals and medical centers, is the provision of quality services at affordable costs. ${ }^{1}$ The quality service implies diagnosing patients properly and administering effective treatments. The available heart disease database consists of both numerical and categorical data. Before further processing, cleaning and filtering are applied on these records in order to filter the irrelevant data from the database. ${ }^{2}$ The proposed system can determine an exact hidden knowledge, ie, patterns and relationships associated with heart disease from a historical heart disease database. It can also answer the complex queries for diagnosing heart disease; therefore, it can be helpful to health care practitioners to make intelligent clinical decisions. Results showed that the proposed system has its unique potency in realizing the objectives of the defined mining goals.

\section{Methods}

The experiment was carried out on a publicly available database for heart disease. The dataset contains a total of 303 records that were divided into two sets, training set
Poornima Singh

Technology, Gujarat Technological

University, S.G. Road, Ahmedabad,

Gujarat 3822 I0, India

Email poornimasingh0806@gmail.com
International Journal of Nanomedicine 2018:I3 (T-NANO 20|4 Abstracts) I2I-124 hereby accept the Terms. Non-commercial uses of the work are permitted without any further permission from Dove Medical Press Limited, provided the work is properly attributed. For permission for commercial use of this work, please see paragraphs 4.2 and 5 of our Terms (https://www.dovepress.com/terms.php). 


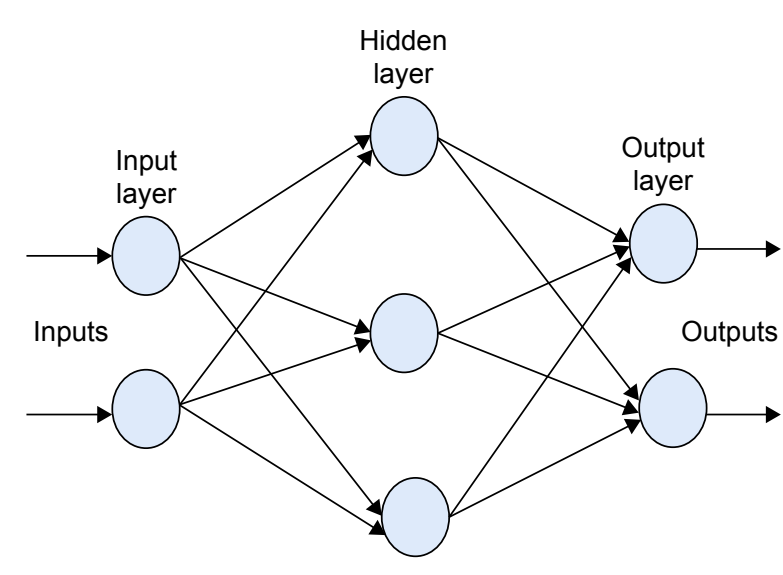

Figure I Multilayer perceptron neural network.

(40\%) and testing set (60\%). A data mining tool named Weka 3.6.11 was used for the experiment. Additionally, multilayer perceptron neural network (MLPNN) with backpropagation (BP) was used as the training algorithm.

\section{MLPNN}

MLPNN is one of the most significant models in artificial neural network. The MLPNN consists of one input layer, one or more hidden layers and one output layer. ${ }^{3}$ In MLPNN, the input nodes pass values to the first hidden layer, and then nodes of first hidden layer pass values to the second and so on till producing outputs as shown in Figure 1.

\section{BP network}

The BP algorithm has served as a useful methodology to train multilayer perceptron for a wide range of applications. ${ }^{4}$ The BP network calculates the difference between real and predicted values, which is circulated from output nodes backwards to nodes in previous layer. The BP learning algorithm can be divided into two phases, propagation and weight update. ${ }^{4}$

First, this learning algorithm provides training data to the network and compares the actual and desired outputs. Then, it calculates the error in each neuron. Based on this, the algorithm calculates what output should be for each neuron and how much higher or lower output must be adjusted for desired output and finally adjusts the weights. The overall process is done to improve weights during processing.

\section{Results and discussion}

In order to predict the probability of patients having heart disease, a confusion matrix (Table 1) was created, where A denotes patients with heart disease, and $\mathrm{B}$ denotes patients with no heart disease.
Table I A confusion matrix

\begin{tabular}{lll}
\hline & $\begin{array}{l}\text { A (patients } \\
\text { with heart } \\
\text { disease) }\end{array}$ & $\begin{array}{l}\text { B (patients } \\
\text { with no heart } \\
\text { disease) }\end{array}$ \\
\hline A (patients with heart disease) & TP & FN \\
B (patients with no heart disease) & FP & TN \\
\hline
\end{tabular}

Abbreviations: TP, true positive; FN, false negative; FP, false positive; TN, true negative.

Table 2 Description of 15 used parameters

\begin{tabular}{|c|c|c|c|}
\hline S no & Parameters & $\begin{array}{l}\text { Parameter } \\
\text { description }\end{array}$ & Values \\
\hline I & age & Age in years & Continuous \\
\hline 2 & sex & Male or female & $\begin{array}{l}\mathrm{I}=\text { male } \\
0=\text { female }\end{array}$ \\
\hline 3 & thestbps & Resting blood pressure & $\begin{array}{l}\text { Continuous value } \\
\text { in } \mathrm{mmHg}\end{array}$ \\
\hline 4 & сP & Chest pain type & $\begin{array}{l}\text { I= typical type I } \\
2=\text { typical type angina } \\
3=\text { non-angina pain } \\
4=\text { asymptomatic }\end{array}$ \\
\hline 5 & chol & Serum cholesterol & $\begin{array}{l}\text { Continuous value } \\
\text { in } \mathrm{mm} / \mathrm{dL}\end{array}$ \\
\hline 6 & fbs & Fasting blood sugar & $\begin{array}{l}I \geq 120 \mathrm{mg} / \mathrm{dL} \\
0 \leq 120 \mathrm{mg} / \mathrm{dL}\end{array}$ \\
\hline 7 & restecg & $\begin{array}{l}\text { Resting electrographic } \\
\text { results }\end{array}$ & $\begin{array}{l}0=\text { normal } \\
\mathrm{I}=\text { having ST-T wave } \\
\text { abnormal } \\
2=\text { left ventricular } \\
\text { hypertrophy }\end{array}$ \\
\hline 8 & thalach & $\begin{array}{l}\text { Maximum heart rate } \\
\text { achieved }\end{array}$ & Continuous value \\
\hline 9 & old peak & $\begin{array}{l}\text { ST depression induced by } \\
\text { exercise relative to rest }\end{array}$ & Continuous value \\
\hline 10 & exang & Exercise induced angina & $\begin{array}{l}0=\text { no } \\
\mathrm{I}=\text { yes }\end{array}$ \\
\hline II & $\mathrm{ca}$ & $\begin{array}{l}\text { Number of major vessels } \\
\text { colored by fluoroscopy }\end{array}$ & $0-3$ value \\
\hline 12 & slope & $\begin{array}{l}\text { Slope of the peak } \\
\text { exercise ST segment }\end{array}$ & $\begin{array}{l}I=\text { unsloping } \\
2=\text { flat } \\
3=\text { downsloping }\end{array}$ \\
\hline 13 & thal & Defect type & $\begin{array}{l}3=\text { normal } \\
6=\text { fixed } \\
7=\text { reversible defect }\end{array}$ \\
\hline 14 & obes & Obesity & $\begin{array}{l}\mathrm{I}=\text { yes } \\
0=\text { no }\end{array}$ \\
\hline 15 & num & $\begin{array}{l}\text { Diagnosis of heart } \\
\text { disease }\end{array}$ & $\begin{array}{l}0 \% \leq 50 \% \\
1 \%>50 \%\end{array}$ \\
\hline
\end{tabular}

Table 3 Results for neural network showing 100\% accuracy

\begin{tabular}{lll}
\hline & $\begin{array}{l}\text { A (patients } \\
\text { with heart } \\
\text { disease) }\end{array}$ & $\begin{array}{l}\text { B (patients } \\
\text { with no heart } \\
\text { disease) }\end{array}$ \\
\hline A (patients with heart disease) & $109(\mathrm{TP})$ & $0(\mathrm{FN})$ \\
$\mathrm{B}$ (patients with no heart disease) & $0(\mathrm{FP})$ & $73(\mathrm{TN})$ \\
\hline
\end{tabular}

Abbreviations: TP, true positive; FN, false negative; FP, false positive; TN, true negative. 


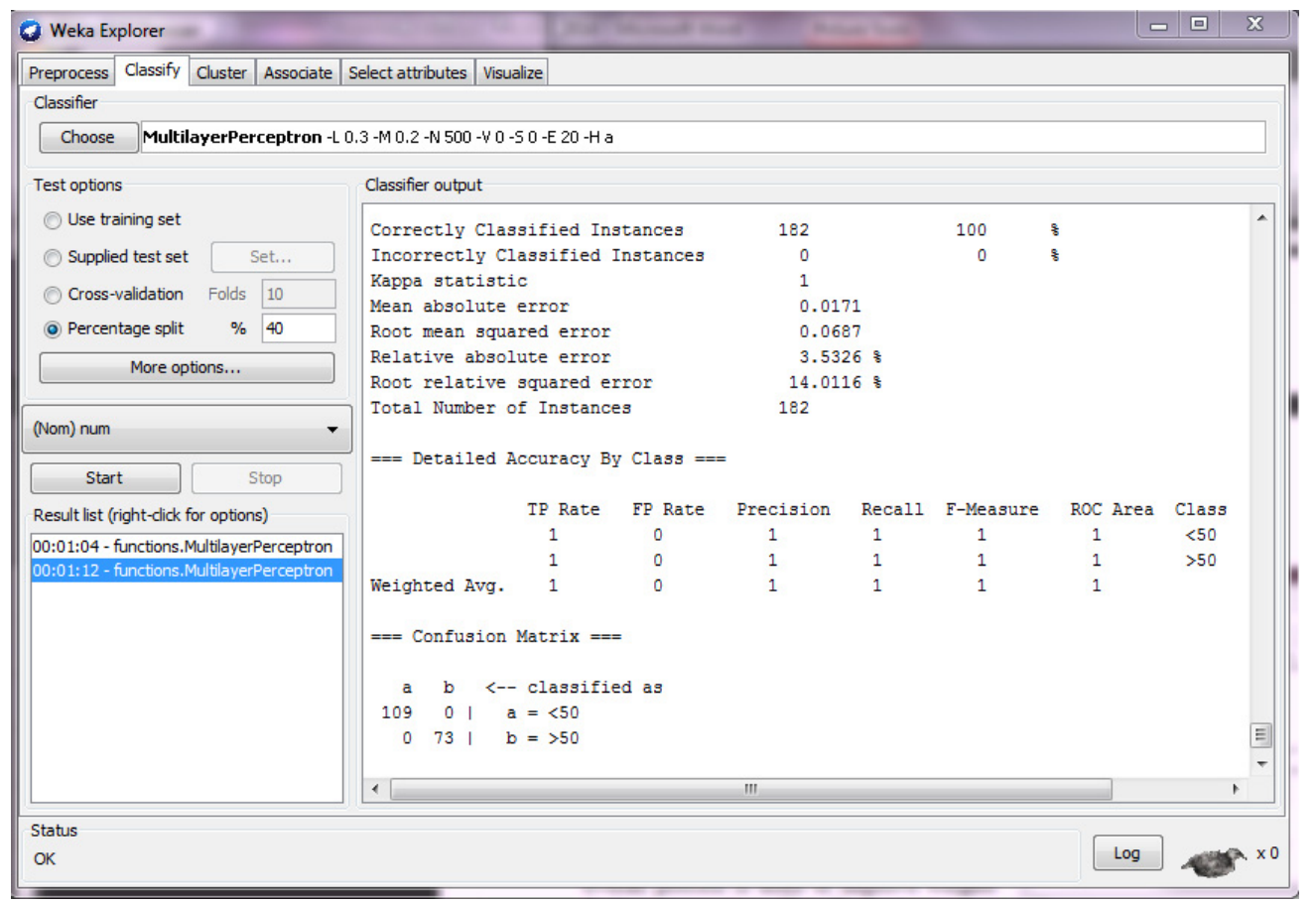

Figure 2 Results showing accuracy for 15 parameters using Weka tool.

A confusion matrix contains information about real and predicted classifications done by a classification system. The data in the matrix are evaluated to know the performance of such systems.

The confusion matrix contains the following four entries:

*TP (true positive): The number of records classified as true while they were actually true.

*FP (false positive): The number of records classified as true while they were actually false.

*FN (false negative): The number of records classified as false while they were actually true.

*TN (true negative): The number of records classified as false while they were actually false.

The overall process of effective heart disease prediction system (EHDPS) is based on the following three steps:

1. Data collection

2. Data pre-processing and

3. The classification of data.

The data are collected from a standard dataset that contains 303 records. The 15 parameters, such as age, sex, chest pain type $(\mathrm{CP})$, and cholesterol (chol), with some domain values associated with them, considered to predict the probability of heart disease are shown in Table 2.

The collected data were used to create a structured database system. The pre-processing was done by identifying the associated fields and removing all the duplications.
After that, all the missing values were filled, and the data were coded according to the domain value.

After applying neural networks on training dataset, the results show that there are zero FN or FP entries (Table 3), suggesting that the system predicts heart disease with $100 \%$ accuracy. Figure 2 shows the actual work done by Weka 3.6.11 tool.

\section{Conclusion}

In this study, an EHDPS has been presented using data mining techniques. From ANN, an MLPNN together with BP algorithm is used to develop the system. The MLPNN model proves the better results and assists the domain experts and even the person related to the medical field to plan for a better and early diagnosis for the patient. This system performs realistically well even without retraining. Furthermore, the experimental results show that the system predicts heart disease with $\sim 100 \%$ accuracy by using neural networks.

\section{Disclosure}

The authors report no conflicts of interest in this work.

\section{References}

1. Palaniappan S, Awang R. Intelligent heart disease prediction system using data mining techniques. Int J Comput Sci Net Secur. 2008;8:343-350.

2. Sayad AT, Halkarnikar PP. Diagnosis of heart disease using neural network approach. Int J Adv Sci Eng Technol. 2014;2:88-92. 
3. Gudadhe M, Wankhade K, Dongre S. Decision support system for heart disease based on support vector machine and Artificial Neural Network. In: Computer and Communication Technology (ICCCT), 2010 International Conference on, 2010:741-745.
4. Rumelhart DE, Hinton GE, Williams RJ. Learning representations by back-propagating error. Nature. 1986;323:533-536.

\section{Publish your work in this journal}

The International Journal of Nanomedicine is an international, peerreviewed journal focusing on the application of nanotechnology in diagnostics, therapeutics, and drug delivery systems throughout the biomedical field. This journal is indexed on PubMed Central, MedLine, CAS, SciSearch ${ }^{\circledR}$, Current Contents ${ }^{\circledR} /$ Clinical Medicine,
Journal Citation Reports/Science Edition, EMBase, Scopus and the Elsevier Bibliographic databases. The manuscript management system is completely online and includes a very quick and fair peer-review system, which is all easy to use. Visit http://www.dovepress.com/ testimonials.php to read real quotes from published authors.

Submit your manuscript here: http://www.dovepress.com/international-journal-of-nanomedicine-journal 